\title{
Multiple regression analysis of epistemological beliefs, learning approaches, and self-regulated learning
}

Huy P. Phan

School of Education, The University of the South Pacific, Suva, Fiji

\section{Republic of Fiji Islands}

Huy P. Phan. School of Education, Room H408, Faculty of Arts and Law, The University of the South Pacific. Suva, Republic of Fiji Islands. E-mail: phan_h@usp.ac.fj

(C) Education \& Psychology $\mathrm{I}+\mathrm{D}+\mathrm{i}$ and Editorial EOS (Spain) 


\begin{abstract}
Introduction. Recent research in educational psychology has explored student approaches to learning (SAL) and epistemological beliefs within the theoretical framework of self-regulated learning. The focus of this research study seeks to explore the predictiveness of learning approaches and epistemological beliefs on students' self-regulatory processes.

Method. 603 (266 females, 337 males) first-year students from the University of the South Pacific participated in this study. The revised Study Process Questionnaire, the Epistemological Beliefs Questionnaire, and various self-regulatory strategies questionnaires were used to measure students' beliefs about their knowledge, learning approaches, and self-regulatory processes.
\end{abstract}

Results. Factor analysis indicated clear patterns of students' beliefs about the nature of knowledge and learning. Various dimensions of epistemological beliefs related to students' self-efficacy beliefs, mastery goal orientation and self-regulatory strategy use. Deep motive to learning related positively with motivational and strategic processes, whereas deep strategy was found to relate with students' self-efficacy beliefs.

Discussion and Conclusion. The findings of our study are significant as they support the theoretical contention and empirical evidence pertaining to the inclusion of both SAL and students' epistemological beliefs within the framework of self-regulation.

Keywords: Epistemological beliefs, learning approaches, self-regulated learning.

Received: 03/15/07 Initial Acceptance: 12/02/07_ Final Acceptance: 04/05/08 


\section{Resumen}

Introducción. Investigaciones recientes de la psicología educativa han explorado los Enfoques al Aprendizaje de los Estudiantes (en ingles, SAL) y las creencias epistemológicas, en el marco teórico del aprendizaje auto-regulado. Estas investigaciones pretenden explorar la capacidad predictora de los enfoques al aprendizaje y las creencias epistemológicas sobre los procesos autorreguladores del alumno.

Método. 603 (266 mujeres, 337 varones) alumnos del primer curso de la Universidad del Pacífico Sur participaron en esta investigación. El Revised Study Process Questionnaire, el Epistemological Beliefs Questionnaire, y varios cuestionarios sobre estrategias autorreguladoras se emplearon para medir las creencias de los alumnos sobre sus propios conocimientos, sus enfoques al aprendizaje, y sus procesos autorreguladores.

Resultados. El análisis de factores manifestó unos patrones claros de creencias de los alumnos en cuanto a la naturaleza del conocimiento y del aprendizaje. Varias dimensiones de las creencias epistemológicas tenían que ver con las creencias de auto-eficacia de los alumnos, una orientación hacia la meta de dominio, y el uso de estrategias autorreguladoras. Motivos profundos para el aprendizaje estaban relacionados positivamente con los procesos motivacionales y estratégicos, mientras una estrategia profunda se relacionaba con las creencias de auto-eficacia del alumno.

Conclusión. Los hallazgos de este estudio son importantes al apoyar la propuesta y la evidencia empírica para incluir tanto los enfoques al aprendizaje como las creencias epistemológicas de los alumnos dentro del marco de la autorregulación.

Palabras clave: Creencias epistemológicas, enfoques al aprendizaje, aprendizaje autorregulado.

Recibido: 15/03/07 Aceptación provisional: 02/12/07 Aceptación definitiva: 05/04/08 


\section{Introduction}

Epistemological beliefs, or students' beliefs and theories about learning and knowledge, have received a considerable amount of attention of late from researchers (Hofer \& Pintrich, 1997; Schraw \& Sinitra, 2004). This line of research inquiry originates from the work of Perry (1970) and indicates the important changes in beliefs (from simple, unchanging facts to complex, tentative concepts) that students go through as they progress in their studies. Extending from Perry's work, advancements have been made in the last decade in examinations of epistemological beliefs from different theoretical perspectives (for example, Baxter Magolda, 1987; Hofer \& Pintrich, 1997; Kitchener \& King, 1981; Ryan, 1984; Schommer, 1990). Schommer's (1990) theoretical orientation, for example, has been pertinent in relating to and explaining students' academic cognition and performance.

Schommer (1990), differing from other epistemological perspectives, offers a more simplistic quantified view of students' beliefs about the nature of knowledge by contending that individuals possess multiple beliefs about the nature of knowledge and learning, and that these beliefs exist as a multidimensional system or more or less independent beliefs. The argumentative premise, in contrast to the work of Perry (1970), Kitchener and King (1981), and Ryan (1984), suggests that personal epistemology is too complex for it to be captured on a unidimensional dimension. The term system according to Schommer refers to the notion that there is more than one belief to consider, and more or less independent suggests that these beliefs could, but not necessarily would, develop in synchrony.

The theoretical lens of Schommer's (1990) perspective posits four dimensions of epistemological beliefs, ranging from naïve to sophisticated: (a) structure of knowledge (ranging from isolated bits to integrated concepts), (b) stability of knowledge (ranging from certain to evolving), (c) speed of learning (from quick or not at all to gradual), and (d) ability to learn (ranging from fixed at birth to improvable)(Schommer, 1994a, 1994b; Schommer-Aikins \& Hutter, 2002). The Epistemological Questionnaire, developed by Schommer, has also provided evidence attesting to the multidimensionality of epistemological beliefs. Existing research investigations indicate mixed results and suggest the need to examine further the dimensionality of personal epistemological beliefs. The work of Phillips, Schommer, and others (Phillips, 2001; Schommer, 1990, 1993; Schommer, Crouse \& Rhodes, 1992; Schommer- 
Aikins, Duell \& Hutter, 2005; Schommer-Aikins \& Hutter, 2002) shows that there are four distinct dimensions of personal epistemology. However, other research studies criticising the use of a priori subsets in factor analysis (Bråten \& Strømsø, 2005) have found at an itembased level of analysis, that three (Cano, 2005; Qian \& Alverman, 1995) to five (Schraw, Bendixen \& Dunkle, 2002) dimensions of epistemology are possible. Other researchers (Bråten \& Strømsø, 2005; Schommer-Aikins, 2004; Wood \& Kardash, 2002) have likewise indicated that examinations of personal epistemology are more optimal when factor-analytic practice is made at an item-based level. In essence, the intention of our study is to explore the dimensions of personal epistemology using a factor-analytic approach that is common.

Examinations of subsequent research studies also indicate that epistemological beliefs predict numerous aspects of academic performance, important amongst them include comprehension, metacomprehension, interpretation of information, higher-order thinking, persistence in working on difficult academic tasks, and problem-solving approaches (Muis, 2004; Schommer, 1993; Schommer et al., 1992; Schommer-Aikins et al., 2005). For example, beliefs about structures and certainty of knowledge predict comprehension, metacomprehension, and interpretation of information. Beliefs about the speed of learning and the ability to learn predict comprehension, valuing of education and overall performance. Other research studies have also examined students' epistemological beliefs in relation to domain-specificity that involves study strategies and problem solving in accounting, history, mathematics, and hypermedia learning (Buehl \& Alexander, 2005; Peng \& Fitzgerald, 2006; Phillips, 2001; Schommer-Aikins et al., 2005).

More recently, epistemological research has linked students' epistemological beliefs to their motivation and self-regulatory strategies (Bråten \& Strømsø, 2005; Hofer \& Pintrich, 1997). Schutz, Pintrich, and Young (1993) found that students with more sophisticated epistemological beliefs were more likely to adopt mastery goals. Findings also indicate that sophisticated epistemological beliefs result in intrinsically motivated students who are highly self-efficacious (Hofer, 1994). Garrett-Ingram (1997) used the Motivated Strategies for Learning Questionnaire (MSLQ: Pintrich, Smith, Garcia \& McKeachie, 1991) to show that simple knowledge was negatively related to self-efficacy beliefs, control beliefs, task value, and intrinsic goal orientation. Furthermore, it was found that students' beliefs in fixed ability were negatively related to their control beliefs. Other research findings have found that naive epistemological beliefs were negatively related to adaptive motivational beliefs such as self- 
efficacy and mastery goal orientation (Neber \& Schommer-Aikins, 2002). Rozendaal, Brabander and Minnaert (2001) also found that students who held sophisticated beliefs of knowledge were more motivated by personal interest in the subject matter.

Other researchers (Bråten \& Strømsø, 2005; Hofer, 2002; Hofer \& Pintrich, 1997) have also pointed out the need to extend the epistemological beliefs research within the theoretical framework of self-regulated learning. This recommendation, made by many authors, suggests that students' epistemological beliefs may function as implicit theories that guide the selection of self-regulatory strategies and provide goals for academic learning (Bråten \& Strømsø, 2005; Hofer \& Pintrich, 1997; Nist \& Simpson, 2000; Pintrich, 2002). In this analysis, students' epistemological beliefs may influence both motivational and strategic components of self-regulated learning. The motivational components of self-regulatory learning emphasise, in many studies, aspects such as students' self-efficacy beliefs, their achievement goal orientations, and their personal interest in the task or the domain (Pintrich, 2000; Zimmerman, 1998, 2000). The recent study by Bråten and Strømsø (2005) is indicative of the importance of epistemological beliefs in students' self-regulated learning. The results indicated that the dimensions of epistemological beliefs and self-regulated learning differed in instructional practices between subject areas. The authors found with Norwegian postsecondary student teachers and business students that their naive epistemological beliefs were negatively related to self-efficacy beliefs, mastery goal orientation, study interest, and selfregulatory strategy use. Notably, differences also existed between the two groups with belief about knowledge construction and modification acting as a stronger predictor of selfregulated learning for the student teachers. For the business students, belief about the certainty of knowledge played an important role in self-regulated learning.

Other research studies in academic settings have also emphasised the importance of motivational and strategic components of self-regulated learning. Findings indicated, for example, that self-efficacy beliefs (Pajares, 1996; Pajares \& Schunk, 2001) and mastery goal orientation (Dweck, 1999; Pintrich, 2000) related positively with students' academic performance. The positive relationship between students' motivation and their academic performance may, in part, be mediated by the use of self-regulatory strategies (Alexander, Graham \& Harris, 1998; Pintrich \& Schunk, 2002). Other researchers also showed that motivational beliefs such as those outlined (self-efficacy, mastery goal orientation) related positively to the planning and selection of self-regulatory strategies (Bråten and Strømsø, 2005). 
There is also evidence which links students' approaches to their learning (SAL) and self-regulatory strategies. Since the 1970's, two approaches to learning have been identified by Marton and Säljö (1976), namely 'deep' and 'surface'. According to the theoretical perspective of SAL, students may adopt a deep approach to learning with an intention to understand the author's meaning and linking it to their prior knowledge and personal experience. In contrast, students may also adopt a surface learning approach where the main emphasis is on studying merely for the intention of reproducing information without any further analysis (Murphy \& Tyler, 2005). Examinations of John Biggs' (1987a) theoretical orientation suggest an additional learning approach - achieving- wherein it is based on achieving motivation and involves strategies that lead to high marks; for example, "study skills" techniques (e.g., good organization, speed reading, effective note-taking) and "cue-conscious" strategies that depend on the learning environment and the extent of teacher involvement (Akande, 1998). The achieving approach is therefore context dependent and the surface and deep approaches relate to rehearsal and the general cognitive processes of coding, respectively (Akande, 1998). Importantly, however, Biggs' (1987a) theoretical conception of study approaches differs from other theorists in two components: how students approach a task (strategy); and why they want to approach it in the first place (motive).

Research into SAL has resulted in the development of different instruments that are used to evaluate students' approaches to their learning in the tertiary context. The two instruments most widely used in research include the Study Process Questionnaire (SPQ)(Biggs, 1987b) and its revised version, the R-SPQ-2F (Biggs, Kember \& Leung, 2001); and the Approaches to Study Inventory (ASI)(Entwistle \& Ramsden, 1983) and its revised version, the RASI (Entwistle \& Tait, 1994). Furthermore, research using these two instruments has explored two main areas of inquiry, namely the relationship between approaches to learning and learning outcomes (e.g., Drew \& Watkins, 1998; Watkins, 2001; Watkins, Regmi \& Astilla, 1991; Wong \& Watkins, 1998; Zeegers, 2001), and the factor structure of SAL (e.g., Biggs et al., 2001; Kember \& Gow, 1991; Kember \& Leung, 1998; Richardson, 1994; Watkins et al., 1991).

More recently, SAL research has advanced in the area of self-regulated learning with findings indicating that learning goal orientations relate to both deep and surface learning strategies (Chan \& Lai, 2002; Kong \& Hau, 1996; Nolen, 1988). In a study involving Hong 
Kong preservice students, Chan and Lai (2002) found that students who scored higher on learning goal orientation were more likely to cognitively engage in deep strategy. Furthermore, students who scored higher on performance goal orientation were likely to engage in both surface and deep learning strategies. Other research studies also provided evidence attesting to the notion that mastery goals are primarily adaptive, relating positively to the use of self-regulatory strategies and other adaptive cognitive strategies that lead towards deeper levels of processing ( $\mathrm{Ng}, 2002)$. Performance goals, in contrast, have detrimental effects on academic learning, as they relate negatively to self-regulatory strategies and positively to shallow processing strategies. In a similar study that involved Hong Kong tertiary students enrolling in a distance mode of learning, $\mathrm{Ng}$ (2002) explored longitudinally the relationships between motivational goals, beliefs, use of strategies, and different learning outcomes. Results of this study revealed that greater use of mastery-development goals was associated with a greater use of adaptive strategies. Performance-approach goals also indicated a similar adaptive pattern strategy use. Importantly, the results showed that mastery goals and self-efficacy beliefs were the most important predictors in influencing different forms of self-regulated and learning strategies over time.

The need to examine SAL within the theoretical framework of self-regulated learning is clearly evident given the limited evidence at present. Previous research studies have examined SAL and aspects of self-regulated learning on an independent basis. Extant findings indicated, for example, that goal orientations related with different approaches to learning. Meece, Blumfeld and Hoyle (1988) found in elementary science classrooms that students with learning goals were more likely to engage in self-regulatory activities, such as the use of cognitive strategies, planning, monitoring, and help-seeking. Kong and Hau (1996) likewise found that learning goals were related to a deep approach and performance goals were associated with a surface approach. Analysis of the evidence suggests then that students orientate towards mastery goals perform academically better than those orientate towards performance goals (Ames, 1992; Greene \& Miller, 1996; Pintrich \& Garcia, 1991).

Aside from research investigations into goal orientations and learning strategies, other research studies have also examined students' self-efficacy beliefs and control beliefs on the use of learning strategies (Ames \& Archer, 1988; Greene \& Miller, 1996; Miller et al., 1993; Pintrich \& DeGroot, 1990). For example, it is found that self-efficacious students who are in control are more likely to use self-regulatory strategies such as time management to regulate 
their learning. Furthermore, students' self-efficacy beliefs have been investigated within the theoretical framework of achievement goals. Greene and Miller (1996) found from path analysis that both self-efficacy beliefs and achievement goals predicted the level of cognitive engagement, which in turn predicted the level of academic performance. In a series of regression analyses, Archer (1994) found that mastery goals contributed to the use of learning strategies, positive learning attitudes, and task choice over and above the contribution of perceived ability and performance goals.

Examinations of previous studies indicate the importance of both epistemological beliefs and SAL in the prediction of self-regulated learning. Although past research has investigated epistemological beliefs and self-regulated learning (Bråten \& Strømsø, 2005; Hofer \& Pintrich, 1997; Nist \& Simpson, 2000) and SAL and self-regulated learning (Chan \& Lai, 2002; Ng, 2002; Meece et al., 1988) on an independent basis, no study to date has tested these relationships in their totality. The work of Bråten and Strømsø (2005), in particular, is fundamental in establishing a precedence for further research investigation into the relationships between epistemological beliefs and learning approaches and different aspects of self-regulated learning. Furthermore, research pertaining to this line of inquiry is pertinent to the understanding of the comparative contributions of both theoretical frameworks on aspects of self-regulated learning.

The research inquiry of personal epistemology and students' learning approaches has also explored these facets in relation to gender differences. Research studies in epistemological beliefs have indicated that female and male students differ in their beliefs about learning and knowledge (Cano, 2005; Galotti, Clinchy, Ainsworth, Lavin \& Mansfield, 1999; Schommer, 1993). Cano (2005), for example, found that Spanish secondary male students' beliefs about quick learning were more unstable throughout secondary education. Girls, in general, express more realistic and elaborate epistemological beliefs than boys. Schommer (1993) found, in contrast, that secondary school girls were less likely to believe in quick learning and fixed ability. The inconclusive findings of genders as such, according to some researchers, may be explained in part by the influences of domains and contexts (Jehng, Johnson \& Anderson, 1993; Lonka \& Lindblom-Ylänne, 1996) as well as instructional practices (Buehl \& Alexander, 2001; Hammer \& Elby, 2002) of subject contents. 
Extant research studies have also explored gender differences in learning approaches as students progress through their secondary and tertiary schooling. Studies from various cultures and settings suggest differing results and indicate the need for further clarification. For example, Smith and Miller (2005) found female university students scored higher than male students on the achieving strategy scale. Likewise, Cano (2005) found with secondary Spanish students that both boys and girls continuously differentiated their approaches to learning as they proceed from junior to high school. Junior high and senior high boys scored more highly on surface approach than junior and senior high girls, and that girls scored higher on deep approach in the senior year. However, disregard of gender, there is a significant decrease reported in all learning approaches, especially, deep approach, as students go through secondary schooling. Eklund-Myrskog and Claes-Göran's (1999) study of Finnish secondary school students showed that girls used a surface strategy to a smaller extent and an achieving strategy to a larger extent than boys. Such gender differences were also previously found by Biggs (1985) and Watkins and Hattie (1990).

\section{Objectives}

Based on the theoretical frameworks presented earlier, the current study examined three major research objectives concerning the relationship between SAL, epistemological beliefs, and various components of self-regulated learning. In particular, the components of self-regulated learning examined in this study included self-efficacy, mastery goal orientations, and students' self-regulatory strategies. Furthermore, students' learning approaches consisted of two main types - deep and surface. Specifically, the questions investigated included: (1) What is the dimensionality of personal epistemology as indicated by an itembased factor analysis of the EQ?; (2) What is the relative contribution of dimensions of personal epistemology and learning approaches to students' self-efficacy beliefs, mastery goal orientations, personal interest, and self-regulatory strategy use?; and (3) Are there any differences in dimensions of personal epistemology and students' approaches to learning between males and females. The current study, in totality, extended the work of Schommer (Schommer, 1993; Schommer et al., 1992; Schommer-Aikins et al., 2005) and Bråten and Strømsø (2005) study with the inclusion of the SAL theoretical framework. 


\section{Method}

\section{Participants and Procedures}

Participants $(N=603 ; 266$ females, 337 males $)$ in this study were all first-year Accounting students enrolled in the regional South Pacific university. The participants' age ranged from 17 to $42(M=20.52, S D=1.49)$. Instruments were administered in tutorial classes with the assistance of four tutors. Participation by the students was voluntary and no remuneration was provided. Students were assured of anonymity and were explained why their responses to the questionnaire were needed. Because of the time constrain, two tutorial classes were needed to complete the three questionnaires.

\section{Instruments}

\section{Study Process Questionnaire (R-SPQ-2F)}

Existing research studies using Biggs' (1987b) Study Process Questionnaire (SPQ) have indicated the recurrent theme that the major learning approaches are best described by a two-factor structure (Kember \& Leung, 1998; Leung \& Kember, 2003; Richardson, 1994). The revised SPQ, developed recently by Biggs et al. (2001), offers an alternative with consistent research evidence supporting for its use (Biggs et al.; Fox, McManus \& Winder 2001; Leung \& Kember, 2003). The R-SPQ-2F consists of 20 items grouped into two approaches deep and surface. Each subscale (e.g., deep motive (DM)) comprised of 5 items answered on a 7-point Likert scale ranging from 1 (always true of me) to 7 (only rarely true of me); for example, "I find that at times studying gives me a feeling of deep personal satisfaction" (deep motive), "I find that I have to do enough work on a topic so that I can form my own conclusions before I am satisfied" (deep strategy), "My aim is to pass the course while doing as little work as possible" (surface motive), and "I only study seriously what's given out in class or in the course outlines" (surface strategy). A full version of the 20 items may be obtained from Biggs et al. Researchers using this instrument have reported reliability estimates ranging from .57 to .72 for the four subscales (Biggs et al.; Leung \& Kember, 2003). The Cronbach's alpha values reported in this study were $.94, .83, .86$, and .92 for the deep motive (DM), deep strategy (DS), surface motive (SM), and surface strategy (SS) subscales, respectively. 


\section{Epistemological Beliefs Questionnaire}

Epistemological beliefs in this study were assessed with the Schommer Epistemological Questionnaire (Schommer, 1990). This 63-item questionnaire has been widely used in previous research (Peng \& Fitzgerald, 2006; Schommer, 1993; Schommer-Aikins \& Hutter, 2002) and taps students' preferences to statements about knowledge and learning. Students respond on a Likert-type scale ranging from strongly disagree (1) to strongly agree (7) to statements, such as "You never know what a book means unless you know the intent of the author" and "It's a waste of time to work on problems which have no possibility of coming out with clear-cut and unambiguous answers." These ratings provide an indication of a participant's range of beliefs along a continuum from a higher score (naïve belief) to a lower score (sophisticated belief). A number of studies have reported that the EQ has good psychometric properties in terms of reliability and content validity. Duell and Schommer-Aikins (2001), for example, reported a .74 test-retest and .63 to a .85 inter-item correlations for items within each belief factor. Furthermore, studies using EFA and CFA have shown that students' responses to the EQ exist as a four-factor structure (Peng \& Fitzgerald, 2006; Phillips, 2001; Schommer, 1990, 1993; Schommer et al., 1992; Schommer-Aikins \& Hutter, 2002).

\section{Self-efficacy, Mastery goal orientation, and Self-regulatory strategies}

Self-efficacy beliefs were measured using the 8 items from the self-efficacy scale of the MSLQ (Pintrich et al., 1991). The 8 items of this measure focus on students' judgements about their capability to accomplish study tasks as well as their confidence to perform those tasks. Students rate items (sample item: 'I am confident I can do an excellent job on the assignments and tests in this study') on a 7-point Likert scale ranging from 1 (not at all true of me) to 7 (very true of me). The Cronbach's alpha value for the self-efficacy scale in this study was .92 .

The self-regulatory strategy measure was also adapted from the MSLQ (Pintrich et al., 1991). Students rate items (sample item: 'I try to think through a topic to decide what I am supposed to learn from it rather than just reading it over when studying for this course') on a 7-point Likert scale ranging from 1 (not at all true of me) to 7 (very true of me). The Cronbach's alpha value for the self-regulatory scale was .92 .

Mastery goal orientation was adapted from Midgley, Kaplan, Middleton, Maehr, Urdan, Anderman, Anderman, and Roeser (1998). In adapting this measure, we reworded the items so that any notion of schooling was deleted. The measure comprised of 6 items descrip- 
tive to learning, self-improvement, and the mastery of challenging tasks. Students rate items (sample item: 'an important reason why I do my work in school is because I want to get better at it') on a 7-point Likert scale ranging from 1 (not at all true) to 7 (very true). The Cronbach's alpha value for the mastery goal orientation scale was .89 .

\section{Statistical Analyses}

In line with procedures used in existing research studies (Bråten \& Strømsø, 2005; Schommer-Aikins et al., 2005; Schommer-Aikins \& Hutter, 2002), we conducted multiple regressions to determine the influence of each of the dependent variables on self-efficacy, mastery goal orientation, and self-regulatory strategies. We computed three regression equations with students' self-efficacy beliefs, mastery goal orientation, and self-regulatory strategies, respectively, as outcome measures. Predictors of each of these equations were the four dimensions of epistemological beliefs, and the two learning approaches. We also included the dichotomous variable of gender (females $=0$, males $=1$ ) to control for any gender differences. MANOVA was then conducted to test for differences by gender on each of the dimensions of epistemology and learning approaches.

\section{Results}

Our first analyses concerned the dimensionality of personal epistemology. In line with previous research studies (Bråten \& Strømsø, 2005; Phillips, 2001; Schommer-Aikins et al., 2005; Schommer-Aikins \& Hutter, 2002), we used exploratory factor analysis (EFA) to explore the dimensions of personal epistemology. Initial analysis yielded 8 factors with eigenvalues greater than 1 and explained 77.3 percent of the total sample variation. Inspection of the scree plot suggested a four-factor solution, with one large factor with an eigenvalue of 9.21 and three other factors with eigenvalues greater than 2 . The other 4 factors had eigenvalues ranging from 1.91 to 1.42 . Given this initial result, we further the EFA by forcing a four-factor solution using varimax rotation. After this analysis, 18 items were deleted because they had eigenvalues of less than .35 on any of the four factors and because they loaded significantly or equally on more than one factor. When a four-factor solution was forced a second time, using the same procedure on the remaining items, four factors with high loadings $(>.40)$ and no cross loading were identified. The final four standardised factors produced by the factor analysis together accounted for 62.98 percent of the variance in responses. Based on the items factoring into the four respective factors, descriptive titles were generated for the 
four factors: Factor 1 is labeled Simple Knowledge (beliefs in simple knowledge); Factor 2 is labeled as Fixed Ability (beliefs that the ability to learn in unchangeable); Factor 3 is labeled as Certain Knowledge (beliefs in certain knowledge); and Factor 4 is labeled as Quick Learning (beliefs in quick, effortless learning). Inter-item reliabilities for items composing each of the four factors, measured by means of Cronbach's alpha values, were .80 for Factor $1, .85$ for Factor 2, .78 for Factor 3, and .76 for Factor 4. Overall, these four factors reflect similarly the factors identified in previous studies.

Our second concern involved the relative contribution of dimensions of epistemological beliefs and learning approaches to aspects of self-regulatory learning. As mentioned previously, we computed three separate regression equations with students' self-efficacy beliefs, mastery goal orientation, and self-regulatory strategies, respectively, as outcome measures. Predictors of each of these three regression equations were the four dimensions of epistemological beliefs and the four dimensions of learning approaches.

For students' self-efficacy beliefs, the nine predictors together explained $15.4 \%$ of the variance in self-efficacy, $F(9,593)=11.95, p<.001$. Table 1 shows both standardised and unstandardised coefficients for the regression equation predicting students' self-efficacy beliefs. The results indicated that deep motive $(\beta=.26, p<.001)$, deep strategy $(\beta=.11, p<$ $.01)$, and simple knowledge $(\beta=.13, p<.01)$ positively predicted self-efficacy, whereas fixed ability $(\beta=-.16, p<.01)$ negatively predicted self-efficacy.

Table 1. Results of multiple regression analysis for variables predicting students' self-efficacy beliefs

\begin{tabular}{lcc}
\hline Variable & $\boldsymbol{\beta}$ & $\boldsymbol{\beta}$ \\
\hline Gender & .07 & .03 \\
Deep motive & .19 & $.26 * * *$ \\
Deep strategy & .11 & $.11 * *$ \\
Surface motive & .06 & .07 \\
Surface strategy & .03 & .05 \\
Fixed ability & -.18 & $-.16 * *$ \\
Certain knowledge & -.02 & -.02 \\
Simple knowledge & .14 & $.13 * *$ \\
Quick learning & .07 & .07 \\
& & \\
\hline
\end{tabular}

Note: $* * p<.01, * * * p<.001$. 
Table 2 shows both standardised and unstandardised coefficients for the regression equation predicting mastery goal orientation. The results revealed that deep motive $(\beta=.15, p$ $<.01)$, simple knowledge $(\beta=.10, p<.05)$, and quick learning $(\beta=.11, p<.05)$ positively predicted mastery goal orientation, whereas both fixed ability $(\beta=-.24, p<.001)$ and certain knowledge $(\beta=-.11, p<.05)$ negatively predicted mastery goal orientation. The nine predictors together explained $12.3 \%$ of the variance in self-efficacy, $F(9,593)=9.24, p<.001$.

Table 2. Results of multiple regression analysis for variables predicting mastery goal orientation

\begin{tabular}{lcc}
\hline Variable & $\boldsymbol{\beta}$ & $\boldsymbol{\beta}$ \\
\hline Gender & .09 & .03 \\
Deep motive & .11 & $.15 * *$ \\
Deep strategy & .05 & .05 \\
Surface motive & .04 & .01 \\
Surface strategy & .01 & .02 \\
Fixed ability & -.29 & $-.24 * * *$ \\
Certain knowledge & -.12 & $-.11 *$ \\
Simple knowledge & .11 & $.10 *$ \\
Quick learning & .12 & $.11 *$ \\
& & \\
\hline \multicolumn{1}{c}{ Note: ${ }^{*} p<.05,{ }^{* *} p<.01,{ }^{* * *} p<.001}$.
\end{tabular}

Finally, the nine predictors together explained a significant portion of the variance, $13.2 \%$, in students' reported use of self-regulatory strategies, $F(9,593)=9.99, p<.001$. Table 3 shows that beliefs about fixed ability $(\beta=-.11, p<.05)$ and simple knowledge $(\beta=-.10$, $p<.05$ ) negatively predicted students' use of self-regulatory strategies, whereas deep motive $(\beta=.19, p<.001)$ made a positive contribution.

Table 3. Results of multiple regression analysis for variables predicting students' self-regulatory strategies

\begin{tabular}{lrr}
\hline Variable & $\boldsymbol{\beta}$ & $\boldsymbol{\beta}$ \\
\hline Gender & -.03 & -.01 \\
Deep motive & .12 & $.19 * * *$ \\
Deep strategy & .04 & .05 \\
Surface motive & -.07 & -.01 \\
Surface strategy & .01 & .02 \\
Fixed ability & -.10 & $-.11 *$ \\
Certain knowledge & -.01 & -.01 \\
Simple knowledge & -.09 & $-.10 *$ \\
Quick learning & -.05 & -.06 \\
& & \\
\hline
\end{tabular}

Note: $* p<.05, * * p<.01, * * * p<.001$. 
The third question in this study concerned differences between males and females in dimensions of epistemological beliefs and learning approaches. A one-way MANOVA was performed to investigate gender differences in the four dimensions of epistemological beliefs. Initial analyses indicated thirty-two cases of univariate outliers and five cases of multivariate outliers at $p=.001$. These thirty-seven cases were deleted from the subsequent analyses. There was no statistically significant difference between males and females on the combined variables, $F(4,563)=1.91, p=.11$; Wilks' Lambda $=.99$; partial $\eta^{2}=.01$. Likewise, a oneway MANOVA showed no statistically significance difference between males and females for the combined variables of learning approaches, $F(4,563)=1.25, p=.29$; Wilks' Lambda $=.99 ;$ partial $\eta^{2}=.01$.

\section{Discussion and Conclusions}

The present study examined three main research objectives: the factor structure of personal epistemological beliefs, the relative contribution of personal epistemological beliefs and learning approaches on students' reported use of self-regulatory strategies, and differences between males and females. Our findings, in general, support previous research studies concerning the distinct dimensions of personal epistemological beliefs and student approaches to learning.

Consistent with previous research studies, our findings show clear patterns of students' beliefs about the nature of knowledge and learning. Exploratory factor analysis at an item-based level indicated that students' personal epistemological beliefs were structured into four main factors. This finding lends support to previous findings reported by Schommer and colleagues (Schommer, 1993; Schommer et al., 1992; Schommer-Aikins et al., 2005; Schommer-Aikins \& Hutter, 2002) concerning the multidimensionality of personal epistemology. The four domains of personal epistemological beliefs in this case refer to beliefs concerning the stability of knowledge, the structure of knowledge, the control of knowledge, and the speed of learning. These results suggest that students in the South Pacific region hold epistemological beliefs that are similar to those held by their Western counterparts.

It is interesting to note the similar findings between the South Pacific and Western societies. The South Pacific is a developing region with distinct philosophies and ethos that differ extensively from the more industrialised and democratic Western societies. Students in 
this region are brought up with a set of cultural identities and ideologies that can then lead to specific beliefs about the nature of learning and knowledge. The fact that a four-factor structure is present in this study comes as a surprise, given that other research studies in Western societies show differences (Bråten \& Strømsø, 2005; Cano, 2005; Phillips, 1998) amongst themselves. For example, Qian and Alvermann (1995) found only three factors - simple knowledge, fixed ability, and quick learning - at an item-based factor analysis. Schraw et al. (2002), in contrast, found five factors of personal epistemology from an item-based level analysis. Researchers have argued then, based on this inconsistency amongst the Western studies, whether the domains of personal epistemology could in fact be distinguished from factor examinations of the SEQ or other instruments alone (Buehl, 2003; Clarebout, Elen, Luyten \& Bamps, 2001).

Our finding concerning the multidimensionality of personal epistemology brings to light the issue of instrumentation (Buehl, 2003; Clarebout et al., 2001). Similar to previous research studies (Bråten \& Strømsø, 2005; Phillips, 2001; Schommer-Aikins et al., 2005), our factor examinations suggest that some items of the SEQ are irrelevant and require a refinement of items. Refinement of items from the SEQ may shed additional insight into the development of students' personal epistemological beliefs in their various domains. Questions concerning the adequacy of inventories such as the SEQ to tap into the various domains of personal epistemology have been raised by researchers (Bråten \& Strømsø, 2005; Buehl, 2003; Schommer-Aikins et al., 2005).

The present study also contributes to the literature on the relationship between personal epistemology and students' reported use of self-regulated strategies. Our findings, consistent with existing research evidence (Bråten \& Strømsø, 2005; Hofer, 1994; Schutz et al., 1993), suggest that students' naïve to sophisticated epistemological beliefs predicted motivational and strategic processes. In particular, within the framework of self-regulated learning we found that domains of naïve epistemological beliefs were negatively related to students' self-efficacy beliefs, mastery goal orientation, and self-regulatory strategy use. Importantly, however, dimensions of personal epistemological beliefs also, to a small extent, positively related to students' self-efficacy and mastery goal orientation. Notably, students with more sophisticated beliefs that learning can be improved over time are more likely to adopt mastery goals, report the use of specific self-regulatory strategies, as well as to feel self-efficacious. Students who believe that knowledge is not absolute but rather tentative are also more likely 
to adopt mastery goals. At the same time, sophisticated beliefs that knowledge is organised in networks of interrelated concepts also lead students to report usage of self-regulatory strategies. Our results then, in line with existing research evidence, suggest then that epistemological beliefs should be included in models of self-regulated learning.

We also found some unexpected results concerning the relationship between epistemological beliefs and motivational and strategic processes. In this analysis, within the framework of self-regulated learning, we found that students who believe that knowledge is organised in isolated bits and pieces are more likely to be self-efficacious and adopt mastery goals. Furthermore, students who believe that learning happens quickly are more likely to adopt mastery goals. It is probable that the personal and cultural ethos and ideologies of the students in this region contribute to this finding. There is a general thinking amongst students, based on their historical and sociocultural upbringings, that learning is mainly concerned with understanding bits and pieces of information in an uncollective manner. It is an institutionalised and societal practice wherein competition, academically, between fellow students is encouraged daily. The argument as such is that students are bounded by the delivery of subject contents in disparate pieces where the outcome plays a more potent role than the actual learning process. The acceptance of this practice leads students then, in general, to feel more self-efficacious in their ability to adopt and master specific goals. Furthermore, there is a tendency for students to learn and acquire knowledge in a quick, decisive orderly fashion that takes very little account of reflection and articulation. The perception from students, in general, is that academic success is achieved by means of rapid, accurate recall of information to the mass. This speculative contention requires further research to clarify the inconclusive findings that we have found.

The results also establish a relationship between SAL and the motivational and strategic components of self-regulated learning. Deep motive to learning was found to relate positively with motivational and strategic processes. Deep strategy, in contrast, was found to relate positively with students' self-efficacy beliefs only. These findings are similar to those described previously in the unpublished studies (Chan \& Lai, 2002; Ng, 2002). In general, the positive relationship between deep motive and strategy and the motivational and strategic processes of self-regulated learning should not come as a surprise. Students who engage in a deep approach to learning do so because they want to master and make sense of the subject matter at hand. This approach to learning and understanding leads students then, to select and 
adopt specific use of motivation and self-regulatory strategies that may assist in towards deeper levels of processing and understanding.

Our results also indicate that, in general, a deep motive to learning is more predictive of the motivational and strategic processes of self-regulated learning than the four dimensions of personal epistemological beliefs. This comparison of predictions between the two theoretical frameworks of SAL and epistemological beliefs is enlightening, as no other research has to date examined this relationship. Despite this significance, our findings also reveal that a surface approach to learning was not statistically related to either the motivational or the strategic components of self-regulation. Further research is needed to verify the issue of how a surface approach to learning is related to both motivational and strategic components of selfregulation. It could be argued that a surface approach is concerned more with reproducing information for the sake of performance outcome and grading (Biggs, 1987a; Murphy \& Tyler, 2005), and students therefore require very little usage of motivational and self-regulatory strategies.

Our results indicate that males and females did not differ in their epistemological beliefs or approaches to learning. These results are somewhat perplexing given that previous research investigations have found both SAL and epistemological beliefs differ by gender (Cano, 2005; Galotti, Clinchy, Ainsworth, Lavin \& Mansfield, 1999; Schommer, 1993). In our opinion, the results of these nonsignificant tendencies between males and females may be attributed to the social context and students' upbringing in the Pacific. The Pacific is a developing region where individuals at an early age, disregard of their genders, are encouraged by societies in general to strive for academic success and achievement. For the majority in the Pacific at large, academic endeavour is seen as an alternative route that may lead to a better life. In fact, many countries in the Pacific region are undergoing a period of social and economical transformation. This involves constant and extensive encouragement and nurturing from parents to their children, disregard of genders, to be competitive and strive for excellence at any cost. Such mindsets are transpired to individuals at a very early age so that there is no differentiation between males and females in their thinking or ideologies. By putting forward this point of view, we are also speculating that there might be differences between the students in the Pacific region and their Western counterparts (Bråten \& Strømsø, 2005; Cano, 2005; Galotti et al., 1999). 
Another reason, in our opinion, that may account for the nonsignificant difference in genders with SAL and the dimensions of personal epistemology is the issue of domains and contexts. Extant research has indicated, for example, that students differ in their epistemological beliefs on the basis of different domains and contexts (Jehng, Johnson \& Anderson, 1993; Lonka \& Lindblom-Ylänne, 1996). Furthermore, other researchers have also suggested that dimensions of epistemological beliefs differ between students because of differing instructional practices (Buehl \& Alexander, 2001; Hammer \& Elby, 2002; Hofer, 2000, 2004). One could argue that differences in domains and instructional practices arise from the socalled 'hard' (e.g., mathematics, science) and 'soft' (e.g., social science, humanities) subjects (Bråten \& Strømsø, 2005; Smith \& Miller, 2005). Students in this study were all from Accounting, a perceived hard subject, and whether this subject commonality might have explained for the nonsignificant gender differences requires further research.

Another direction for future research involves exploring how the theoretical frameworks of SAL and personal epistemology might be mediated by the components of selfregulation and explain academic performance. Previous research investigations (Bråten \& Strømsø, 2005; Chan \& Lai, 2002; Ng, 2002) have in general examined students' epistemological beliefs and learning approaches in the absence of their academic performances. The use of structural equation modelling (SEM) could provide additional insight into the causal and mediating interrelationships between the three theoretical frameworks and academic performance (Bollen, 1989; Kline, 2005). The direction of cause-and-effect between SAL, personal epistemology, components of self-regulated learning, and academic performance, for example, may be investigated by using longitudinal data with SEM.

The results of our study, in general, provide theoretical contribution to the existing literature on personal epistemology and students' approaches to their learning. Consonant with previous research investigations, the current study supports the theoretical contention and empirical evidence pertaining to the inclusion of both SAL and students' epistemological beliefs within the framework of self-regulation. Thus within the theoretical framework of self-regulation, it was found that dimensions of personal epistemological beliefs predicted both motivational and strategic components of self-regulated learning. Furthermore, the deep approach to learning contributed to the overall variance of both motivational and strategic processes. 


\section{References}

Akande, A. (1998). Towards the multicultural validation of a western model of student approaches to learning. Education, 119(1), 37-47.

Alexander, P. A., Graham, S., \& Harris, K. R. (1998). A perspective on strategy research: Progress and prospects. Educational Psychology Review, 10, 129-154.

Ames, C. (1992). Classrooms: Goals, structures, and student motivation. Journal of Educational Psychology, 84(3), 261-271.

Ames, C. \& Archer, J. (1988). Achievement goals in the classroom: Students' learning strategies and motivational processes. Journal of Educational Psychology, 80(3), 260267.

Archer, J. (1994). Achievement goals as measure of motivation in university students. Contemporary Educational Psychology, 19, 430-446.

Baxter Magolda, M. B. (1987). The affective dimension of learning: Faculty-student relationships that enhance intellectual development. College Student Journal, 21, 46-58.

Biggs, J. B. (1985). The role of metalearning in study processes. British Journal of Educational Psychology, 55, 185-212.

Biggs, J. (1987a). Student approaches to learning and studying. Melbourne: Australian Council for Educational Research.

Biggs, J. (1987b). The Study Process Questionnaire (SPQ): Manual. Hawthorn, Victoria: Australian Council for Educational Research.

Biggs, J., Kember, D., \& Leung, D. Y. P. (2001). The revised two-factor Study Process Questionnaire: R-SPQ-2F. British Journal of Educational Psychology, 63(3), 133-149.

Bollen, K. A. (1989). Structural equations with latent variables. New York City: Wiley.

Bråten, I. \& Strømsø, H. I. (2005). The relationship between epistemological beliefs, implicit theories of intelligence, and self-regulated learning among Norwegian postsecondary students. British Journal of Educational Psychology, 75, 539-565.

Buehl, M. M. (2003). At the crossroads: Exploring the intersection of epistemological beliefs, motivation, and culture. Paper presented at the annual conference of American Educational Research Association, Chicago. 
Buehl, M. M. \& Alexander, P. A. (2001). Beliefs about academic knowledge. Educational Psychology Review, 13, 385-418.

Buehl, M. M. \& Alexander, P. A. (2005). Motivation and performance differences in students' domain-specific epistemological belief profiles. American Educational Research Journal, 42(4), 697-726.

Cano, F. (2005). Epistemological beliefs and approaches to learning: Their change through secondary school and their influence on academic performance. British Journal of Educational Psychology, 75, 203-221.

Chan, K. \& Lai, P. (2002). An exploratory study of the relation between achievement goal orientations and study strategies. Paper presented at Self-concept research: Driving international research agendas. Retrieved $22^{\text {nd }}$ June 2006 from http://self.uws.edu.au/conferences/2002_Chan_\&Lai.pdf.

Clarebout, G., Elen, J., Luyten, L., \& Bamps, H. (2001). Assessing epistemological beliefs: Schommer's Questionnaire revisited. Educational Research and Education, 7, 53-77.

Drew, P. \& Watkins, D. (1998). Affective variables, learning approaches and academic achievement: A causal modeling investigation with Hong Kong tertiary students. British Journal of Educational Psychology, 68, 173-188.

Duell, O. K. \& Schommer-Aikins, M. (2001). Measures of people's beliefs about knowledge and learning. Educational Psychology Review, 13, 419-449.

Dweck, C. S. (1999). Self-theories: Their role in motivation, personality, and development. Philadelphia: Psychology Press.

Eklund-Myrskog, G. \& Claes-Göran, W. (1999). Students' approaches to learning in Finnish general upper secondary school. Scandinavian Journal of Educational Research, 43(1), 5-18.

Entwistle, N. J. \& Ramsden, P. (1983). Understanding student learning. London: Croom Helm.

Entwistle, N. J. \& Tait, H. (1994). The Revised Approaches to Study Inventory. Edinburgh University: Centre for Research into Learning and Instruction. 
Fox, A. R., McManus, I. C., \& Winder, B. C. (2001). The shortened Study Process Questionnaire: An investigation of its structure and longitudinal stability using confirmatory factor analysis. British Journal of Educational Psychology, 71, 511-530.

Galotti, K. M., Clinchy, B. McV., Ainsworth, K. H., Lavin, B., \& Mansfield, A. F. (1999). A new way of assessing ways of knowing: The Attitudes Toward Thinking and Learning Survey (ATTLS). Sex Roles, 40, 745-765.

Garrett-Ingram, C. (1997, March). Something to believe in: The relationship between epistemological beliefs and study strategies. Paper presented at the annual meeting of the American Educational Research Association, Chicago.

Greene, B. A. \& Miller, R. B. (1996). Influences on achievement: Goals, perceived ability, and cognitive engagement. Contemporary Educational Psychology, 21, 181-192.

Hammer, D. \& Elby, A. (2002). On the form of a personal epistemology. In B. K. Hofer \& P. R. Pintrich (Eds.), Personal epistemology: The psychology of beliefs about knowledge and knowing (pp. 169-190). Mahwah, NJ: Erlbaum.

Hofer, B. K. (1994, August). Epistemological beliefs and first-year college students: Motivation and cognition in different instructional contexts. Paper presented at the annual meeting of the American Psychological Association, Los Angeles.

Hofer, B. K. (2000). Dimensionality and disciplinary differences in personal epistemology. Contemporary Educational Psychology, 25, 378-405.

Hofer, B. K. (2002). Personal epistemology as a psychological and educational construct: An introduction. In B. K. Hofer \& P. R. Pintrich (Eds.), Personal epistemology: The psychology of beliefs about knowledge and knowing (pp. 3-13). Mahwah, NJ: Erlbaum.

Hofer, B. K. (2004). Exploring the dimensions of personal epistemology in differing classroom contexts: Student interpretations during the first year of college. Contemporary Educational Psychology, 29, 129-163.

Hofer, B. K. \& Pintrich, P. R. (1997). The development of epistemological theories: Beliefs about knowledge and knowing and their relation to learning. Review of Educational Research, 67, 88-140.

Jehng, J. J., Johnson, S. D., \& Anderson, R. C. (1993). Schooling and students' epistemological beliefs about learning. Contemporary Educational Psychology, 18, 23-35. 
Kember, D. \& Gow, L. (1991). A challenge to the anecdotal stereotype of the Asian student. Studies in Higher Education, 16, 117-128.

Kember, D. \& Leung, D. Y. P. (1998). The dimensionality of approaches to learning: an investigation with confirmatory factor analysis on the structure of the SPQ and LPQ. British Journal of Educational Psychology, 68, 395-407.

Kitchener, K. S. \& King, P. M. (1981). Reflective judgment: Concepts of justification and their relationship to age and education. Journal of Applied Developmental Psychology, 2, 89-116.

Kline, R. B. (2005). Principles and practice of structural equation modelling ( $2^{\text {nd }}$ ed). New York: Guildford.

Kong, C. \& Hau, K. (1996). Students' achievement goals and approaches to learning: the relationship between emphasis on self-improvement and thorough understanding. Research in Education, 55, 74-85.

Leung, D. Y. P. \& Kember, D. (2003). The relationship between approaches to learning and reflection upon practice. Educational Psychology, 23(1), 61-71.

Lonka, K. \& Lindblom-Ylänne, S. (1996). Epistemologies, conceptions of learning, and study practices in medicine and psychology. Higher Education, 31, 5-24.

Marton, F. \& Säljö, R. (1976). On qualitative differences in learning - I: Outcome and process. British Journal of Educational Psychology, 46, 4-11.

Meece, J. L., Blumfeld, P. C., \& Hoyle, R. K. (1988). Students' goal orientations and cognitive engagement in classroom activities. Journal of Educational Psychology, 80, 514523.

Midgley, C., Kaplan, A., Middleton, M., Maehr, M. L., Urdan, T., Anderman, L. H., Anderman, E., \& Roeser, R. (1998). The development and validation of scales assessing students' achievement goal orientations. Contemporary Educational Psychology, 23, 113-131.

Miller, R. B., Behrens, J. T., Greene, B. A., \& Newman, D. (1993). Goals and perceived ability: Impact on student valuing, self-regulation, and persistence.

Muis, K. R. (2004). Personal epistemology and mathematics: A critical review and synthesis of research. Review of Educational Research, 74(3), 317-377. 
Murphy, S. M. \& Tyler, S. (2005). The relationship between learning approaches to part-time study of management courses and transfer of learning to the workplace. Educational Psychology, 25(5), 455-469.

Neber, H. \& Schommer-Aikins, M. (2002). Self-regulated science learning with highly gifted students: The role of cognitive, motivational, epistemological, and environmental variables. Higher Ability Studies, 13, 59-74.

Ng, C. (2002). Relations between motivational goals, beliefs, strategy use and learning outcomes among university students in a distance learning mode: A longitudinal study. Paper presented at the annual conference of Australian Association for Research in Education, Brisbane. Retrieved 22 $2^{\text {nd }}$ June 2006 from www.aare.edu.au/02pap/ng02462.html.

Nist, S. L. \& Simpson, M. L. (2000). College studying. In M. L. Kamil, P. B. Mosenthal, P. D. Pearson \& R. Barr (Eds.), Handbook of reading research (Vol. 3, pp. 645-666). Mahwah, NJ: Erlbaum.

Pajares, F. (1996). Self-Efficacy beliefs in academic settings. Review of Educational Research, 66(4), 543-578.

Pajares, F. \& Schunk, D. H. (2001). Self-beliefs and school success: Self-efficacy, selfconcept, and school achievement. In R. Riding \& S. Rayner (Eds.), Perception (pp. 239-266). London: Ablex Publishing.

Peng, H. \& Fitzgerald, G. E. (2006). Relationships between teacher education students' epistemological beliefs and their learning outcomes in a case-based hypermedia learning environment. Journal of Technology and Teacher Education, 14(2), 255-285.

Perry, W. G., Jr. (1970). Forms of intellectual and ethical development in the college years. New York: Academic Press.

Phan, H. (2006). Examination of student learning approaches, reflective thinking, and epistemological beliefs: A latent variables approach. Electronic Journal of Research in Educational Psychology, 4(3), 577-610.

Phillips, F. (1998). Accounting students' beliefs about knowledge: Associating performance with underlying belief dimensions. Issues in Accounting Education, 13, 113-125. 
Phillips, F. (2001). A research note on accounting students' epistemological beliefs, study strategies, and unstructured problem-solving performance. Issues in Accounting Education, 16(1), 21-39.

Pintrich, P. R. (2000). The goal orientation in self-regulated learning. In M. Boekaerts, P. R. Pintrich, \& M. Zeidner (Eds.), Handbook of self-regulation (pp. 451-502). San Diego: Academic Press.

Pintrich, P. R. (2002). Future challenges and directions for theory and research on personal epistemology. In B. K. Hofer \& P. R. Pintrich (Eds.), Personal epistemology: The psychology of beliefs about knowledge and knowing (pp. 389-414). Mahwah, NJ: Erlbaum.

Pintrich, P. R. \& DeGroot, V. (1990). Motivational and self-regulated learning components of classroom academic performance. Journal of Educational Psychology, 82(1), 3340.

Pintrich, P. R. \& Garcia, T. (1991). Student goal orientation and self-regulation in the college classroom. In M. L. Maehr \& P. R. Pintrich (Eds.), Advances in motivation and achievement (Vol. 7, pp. 371-402). Greenwich CT: JAI Press.

Pintrich, P. R. \& Schunk, D. H. (2002). Motivation in education: Theory, research, and applications. Upper Saddle River, NJ: Merrill Prentice Hall.

Pintrich, P. R., Smith, D. A. F., Garcia, T., \& McKeachie, W. J. (1991). A manual for the use of the Motivated Strategies for Learning Questionnaire (MSLQ). Ann Arbor, MI: National Center for Research to Improve Postsecondary Teaching and Learning, University of Michigan.

Qian, G. \& Alvermann, D. (1995). Role of epistemological beliefs and learned helplessness in secondary school students' learning science concepts from text. Journal of Educational Psychology, 87, 282-292.

Richardson, J. T. E. (1994). Cultural specificity of approaches to studying in higher education. Higher Education, 27, 449-468.

Rozendaal, J. S., Brabander, de C. J., \& Minnaert, A. (2001). Boundaries and dimensionality of epistemological beliefs. Paper presented at the biennial meeting of the European Association for Research on Learning and Instruction, Fribourg, Switzerland. 
Ryan, M. P. (1984). Monitoring text comprehension: Individual differences in epistemological standards. Journal of Educational Psychology, 76, 248-258.

Schommer, M. (1990). Effects of beliefs about the nature of knowledge on comprehension. Journal of Educational Psychology, 82, 498-504.

Schommer, M. (1993). Epistemological development and academic performance among secondary students. Journal of Educational Psychology, 85, 406-411.

Schommer, M. (1994a). An emerging conceptualisation of epistemological beliefs and their role in learning. In R. Garner \& P. A. Alexander (Eds.), Beliefs about text and instruction with text (pp. 25-40). Hillsdale, NJ: Lawrence Erlbaum.

Schommer, M. (1994b). Synthesizing epistemological beliefs research: Tentative understandings and provocative confusions. Educational Psychology Review, 6(4), 293-319.

Schommer, M., Crouse, A. \& Rhodes, N. (1992). Epistemological beliefs and mathematical text comprehension: Believing it's simple doesn't make it so. Journal of Educational Psychology, 84, 435-443.

Schommer-Aikins, M. (2004). Explaining the epistemological beliefs system: Introducing the embedded systemic model and coordinated research approach. Educational Psychologist, 39, 19-29.

Schommer-Aikins, M., Duell, O. K., \& Hutter, R. (2005). Epistemological beliefs, mathematical problem-solving beliefs, and academic performance of middle school students. The Elementary School Journal, 105(3), 289-304.

Schommer-Aikins, M. \& Hutter, R. (2002). Epistemological beliefs and thinking about everyday controversial issues. The Journal of Psychology, 136(1), 5-20.

Schraw, G., Bendixen, L. D., \& Dunkle, M. E. (2002). Development and validation of the Epistemic Belief Inventory (EBI). In B. K. Hofer \& P. R. Pintrich (Eds.), Personal epistemology: The psychology of beliefs about knowledge and learning (pp. 261-275). Mahwah, NJ: Erlbaum.

Schraw, G. \& Sinatra, G. M. (2004). Epistemological development and its impact on cognition in academic domains. Contemporary Educational Psychology, 29, 95-102. 
Schutz, P. A., Pintrich, P. R., \& Young, A. J. (1993, April). Epistemological beliefs, motivation, and student learning. Paper presented at the annual meeting of the American Educational Research Association, Atlanta.

Smith, S. N. \& Miller, R. J. (2005). Learning approaches: Examination type, discipline of study, and gender. Educational Psychology, 25(1), 43-53.

Watkins, D. (2001). Correlates of approaches to learning: A cross-cultural meta-analysis. In R. Sternberg \& L. F Zhang (Eds.), Perspectives on thinking, learning, and cognitive styles (pp. 165-195). Mahwah, NJ: Lawrence Erlbaum.

Watkins, D. \& Hattie, J. (1990). Individual and contextual differences in the approaches to learning of Australian secondary school students. Educational Psychology, 10, 333342.

Watkins, D., Regmi, M., \& Astilla, E. (1991). The Asian learner as a rote learner stereotype: Myth or reality. Educational Psychology, 11, 21-34.

Wood, P. \& Kardash, C. (2002). Critical elements in the design and analysis of studies of epistemology. In B. K. Hofer \& P. R. Pintrich (Eds.), Personal epistemology: The psychology of beliefs about knowledge and knowing (pp. 231-260). Mahwah, NJ: Erlbaum.

Wong, N. \& Watkins, D. (1998). A longitudinal study of psychosocial environment and learning approaches in the Hong Kong classroom. Journal of Educational Research, 91, 247-254.

Zeegers, P. (2001). Approaches to learning in science: A longitudinal study. British Journal of Educational Psychology, 71, 115-132.

Zimmerman, B. J. (1998). Developing self-fulfilling cycles of academic regulation: An analysis of exemplary instructional models. In D. H. Schunk \& B. J. Zimmerman (Eds.), Self-regulated learning: From teaching to reflective practice (pp. 1-19). New York: Guildford Press.

Zimmerman, B. J. (2000). Attaining self-regulation: A social cognitive perspective. In M. Boekaerts, P. R. Pintrich \& M. Zeidner (Eds.), Handbook of self-regulation (pp. 1339). San Diego: Academic Press. 